\title{
Arteriovenous fistula after ventriculostomy in aneurysmal subarachnoid hemorrhage
}

Figure Arteriovenous fistula after ventriculostomy in aneurysmal subarachnoid hemorrhage

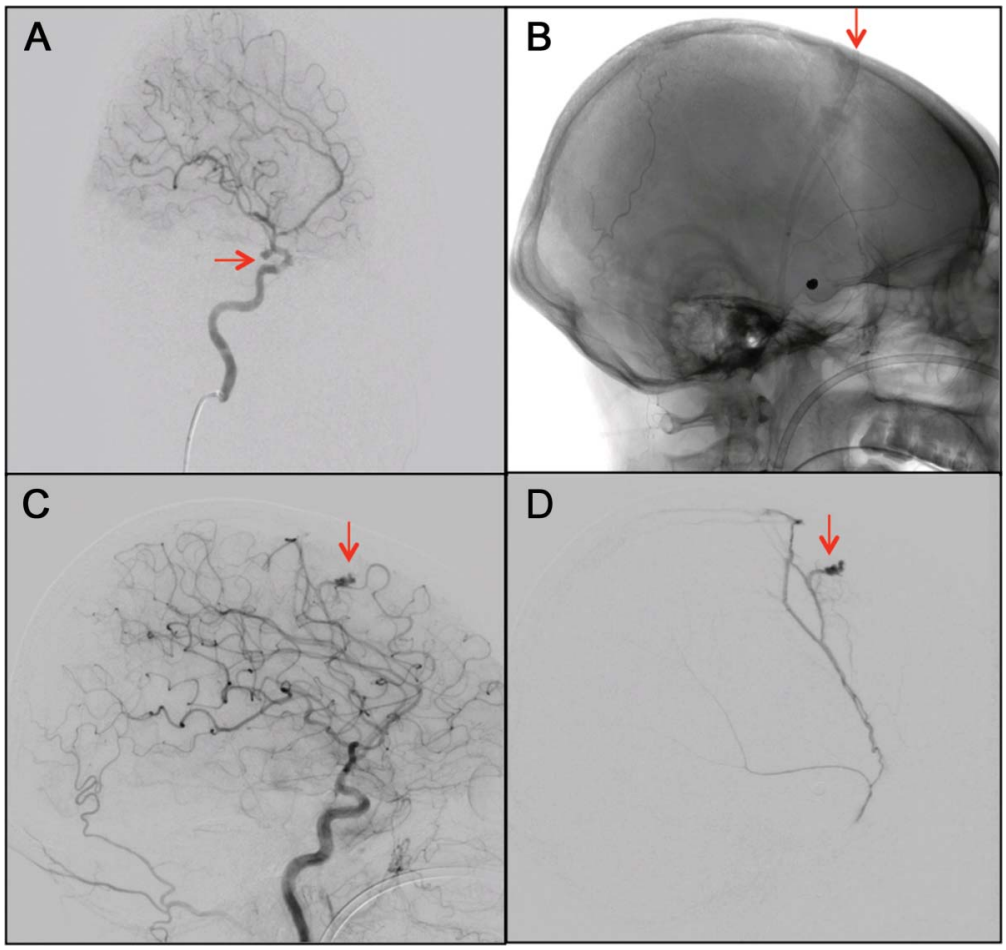

(A) Initial angiogram prior to ventriculostomy demonstrates a right posterior communicating artery aneurysm (arrow). (B) A right ventriculostomy (arrow) was placed. (C, D) After ventriculostomy, a new arteriovenous fistula (arrow) was found during a right carotid artery angiogram.

A 66-year-old woman was found unresponsive after complaining of severe headache several days prior. She was comatose upon initial evaluation and a cranial CT revealed diffuse subarachnoid hemorrhage. A right posterior communicating artery aneurysm (figure, A, arrow) was successfully treated with endovascular embolization. Conventional angiography performed 7 days following ventriculostomy placement for hydrocephalus demonstrated interval development of a traumatic arteriovenous fistula (AVF) filling by the middle meningeal artery (figure, $\mathrm{C}$ and D, arrows). The AVF was treated with intra-arterial embolization. Ventriculostomy-associated AVF has rarely been reported. ${ }^{1}$ Outcomes of untreated iatrogenic AVF are unknown, but could lead to hemorrhagic complications.

Karl Meisel, MD, Alan Yee, DO, Charles Stout, MD, Warren Kim, MD, Daniel Cooke, MD, Van Halbach, MD From the University of California San Francisco, San Francisco.

Author contributions: Karl Meisel: prepared images and wrote the clinical summary. Alan Yee: assisted in clinical summary with literature review and revisions. Charles Stout: obtained images. Warren Kim: obtained images and revisions. Daniel Cooke: obtained images. Van Halbach: faculty advisor, obtained images, assisted with design and content of summary presentation.

Study funding: No targeted funding reported.

Disclosure: The authors report no disclosures relevant to the manuscript. Go to Neurology.org for full disclosures.

Correspondence to Dr. Meisel: meiselk@gmail.com

1. Field M, Branstetter BF, Levy E, Yonas H, Jungreis CA. Dural arteriovenous fistula after ventriculostomy: case illustration. J Neurosurg 2002;97:227. 


\title{
Neurology
}

\author{
Arteriovenous fistula after ventriculostomy in aneurysmal subarachnoid hemorrhage \\ Karl Meisel, Alan Yee, Charles Stout, et al. \\ Neurology 2013;80;2168 \\ DOI 10.1212/WNL.0b013e318295d66f
}

This information is current as of June 3, 2013

Updated Information \&
Services

References

Subspecialty Collections

Permissions \& Licensing

Reprints including high resolution figures, can be found at: http://n.neurology.org/content/80/23/2168.full

This article cites 1 articles, 0 of which you can access for free at: http://n.neurology.org/content/80/23/2168.full\#ref-list-1

This article, along with others on similar topics, appears in the following collection(s):

\section{All Cerebrovascular disease/Stroke}

http://n.neurology.org/cgi/collection/all_cerebrovascular_disease_strok e

\section{Arteriovenous malformation}

http://n.neurology.org/cgi/collection/arteriovenous_malformation Subarachnoid hemorrhage

http://n.neurology.org/cgi/collection/subarachnoid_hemorrhage

Information about reproducing this article in parts (figures,tables) or in its entirety can be found online at:

http://www.neurology.org/about/about_the_journal\#permissions

Information about ordering reprints can be found online:

http://n.neurology.org/subscribers/advertise

Neurology ${ }^{\circledR}$ is the official journal of the American Academy of Neurology. Published continuously since 1951, it is now a weekly with 48 issues per year. Copyright (C 2013 American Academy of Neurology. All rights reserved. Print ISSN: 0028-3878. Online ISSN: 1526-632X.

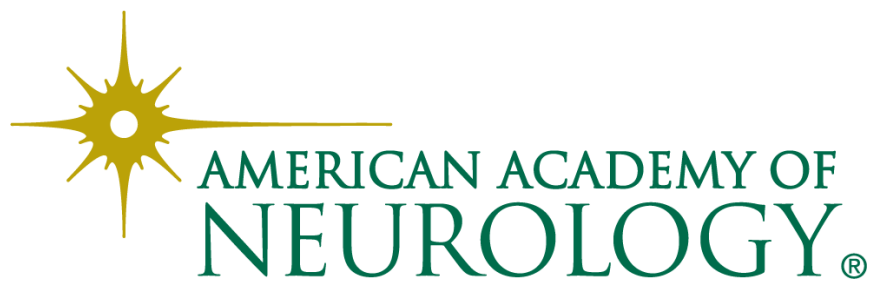

